\title{
EUROPE, APORETICALLY: A COMMON LAW WITHOUT A COMMON DISCOURSE
}

\author{
Simone Glanert*
}

There is no communication because there are no vehicles of communication.

- Samuel Beckett ${ }^{1}$

\begin{abstract}
In response to the European Union's avowed ambition to elaborate a uniform European private law, some critics have maintained that uniformisation is illusory on account of the disparities between the governing legal languages within the different Member States. This objection has, in its turn, given rise to an argument according to which uniformisation could be ensured through the emergence of a common discourse. It has been said that such outcome is possible even in the absence of a common language. For the proponents of this claim, the theory of communicative action developed by Jürgen Habermas offers significant support. By way of reaction to the common-discourse thesis, this paper proposes to explain why it cannot be sustained and why one cannot usefully draw inspiration from Habermas's thinking in order to promote a uniform private law within the European Union.
\end{abstract}

Keywords: European Union; uniformisation of laws; language; discourse

A Swiss lawyer, offering an outsider's view on current legal developments within the European Union, has recently remarked that 'European contract law, a relatively novel idea, is a little like an anthill under full construction'. ${ }^{2}$ Following upon various initiatives from the European Commission, most of them taking the form of directives strictly delimited in their scope, for example to the field of consumer law, many projects have been developed in order to actively promote the unification or harmonization the uniformisation - of contract law within the European Union. ${ }^{3}$ Thus, over the past few years, task forces such as the 'Commission on European Contract Law' and the 'Research Group on EC Private Law' (also known as the 'Acquis Group') have been trying to formulate general principles in European contract law. Other research teams, like the 'Study Group on a European Civil Code', have firmly sought to foster the implementation of a European code of contract law. ${ }^{4}$

\footnotetext{
Senior Lecturer in French and European Comparative Law, Kent Law School, Eliot College, Canterbury, Kent, CT2 7NS, UK; S.Glanert@kent.ac.uk. I presented early formulations of this argument at the RELINE Network for Interdisciplinary Studies in Language and the Law Seminar, Faculty of Law, University of Copenhagen, on 25 October 2011; at the Faculté de Droit, Université de Montréal, on 27 January 2012; at the $4^{\text {th }}$ Annual Meeting of the Irish Society of Comparative Law (ISCL), Faculty of Law, University of Cork, on 2 March 2012; and at the Faculté de Droit, Université de Grenoble, on 22 March 2012. I am grateful to Anne Lise Kjær, Jean-François Gaudreault-DesBiens, Bénédicte Fuller-Sage and David Dechenaud for their kind expression of interest in my work and generous invitations.

$1 \quad$ S. Beckett, 'Proust', in P. Auster (ed.), The Grove Centenary Edition, Vol. IV (2006), at 539 [1931].

2 P. Pichonnaz, 'Les principes en droit européen des contrats: de règles communes à une compréhension partagée', in S. Besson and P. Pichonnaz (eds.), Les principes en droit européen (2011), at 218 ['le droit des contrats européen, une notion en soi relativement récente, est un peu comme une fourmilière en pleine construction'].

See, for panoramas of the different working groups seeking to lay the foundations for a European private law, R. Zimmermann, 'The Present State of European Private Law', 57 American Journal of Comparative Law 479 (2009); W. Wurmnest, 'Common Core, Grundregeln, Kodifikationsentwürfe, Acquis-Grundsätze - Ansätze internationaler Wissenschaftlergruppen zur Privatrechtsvereinheitlichung in Europa', Zeitschrift für Europäisches Privatrecht 714 (2003).

4 See C. von Bar and O. Lando, 'Communication on European Contract Law: Joint Response of the
} 
Though plans for a fully fledged codification of the whole of private law seem to be at a standstill for the time being, the idea of a European law of contract continues to be vigorously championed. In 2009, acting on a request from the European Commission, the 'Study Group on a European Civil Code' and the 'Acquis Group' produced a 'Draft Common Frame of Reference' in the form of six bulky volumes. ${ }^{5}$ On 3 May 2011, still at the behest of the European Commission, a committee of experts released a 'feasibility report' regarding the application of a 'Common Frame of Reference'. ${ }^{6}$ And, on 11 October 2011, after a favourable opinion had been expressed by the European Parliament, in line with its various resolutions since $1989,{ }^{7}$ the European Commission suggested to Member States the adoption of a regulation concerning the implementation of an optional European sales law. ${ }^{8}$ Since then, this proposal has led to animated political debates, for example in Germany, Austria and the United Kingdom.

Much ink has been spilled (or, rather, many pixels have been generated) on account of the idea of a European private law. Several legal scholars welcome this agenda with enthusiasm. ${ }^{9}$ It is argued that uniformisation of law constitutes an appropriate and effective means for the elimination of differences across national civil-law legislations that obstruct the optimal functioning of the European Common Market. Moreover, it is suggested that uniform civil-law legislation will help foster or consolidate the existence of a common European identity. Other scholars, by contrast, have severely criticized the legal integration process. ${ }^{10}$ In particular, some authors claim that the rich European legal diversity, characterized by the presence of at least two fundamentally different forms of legal knowledge - the civil-law tradition, presenting a 'nomothetic fabric' on the one hand, and the common-law tradition, showing an 'idiographic allegiance' on the other - cannot be reconciled with projects that strive for the institution of a uniform way of thinking, an idea that would stand in profound contradiction to 'what has been promised under the name Europe'. ${ }^{11}$

Commission on European Contract Law and the Study Group on a European Civil Code', 10 European Review of Private Law 183 (2002).

5 C. von Bar and E. Clive (eds.), Principles, Definitions and Model Rules of European Private Law: Draft Common Frame of Reference, 6 Vols. (2009). See, generally, M.W. Hesselink, 'The Common Frame of Reference As a Source of European Private Law', 83 Tulane Law Review 919 (2009).

6 European Commission, 'A European Contract Law for Consumers and Businesses: Publication of the Results of the Feasibility Study Carried Out by the Expert Group on European Contract Law for Stakeholders' and Legal Practitioners' Feedback', 3 May 2012, <www.ec.europa.eu> (accessed on 10 August 2012).

See, in particular, Resolution [of the European Parliament] on Action to Bring into Line the Private Law of the Member States, [1989] OJ C158/400 (26 May 1989); Resolution [of the European Parliament] on the Harmonization of Certain Sectors of the Private Law of the Member States, [1984] OJ C205/518 (6 May 1994); Resolution [of the European Parliament] on the Approximation of the Civil and Commercial Law of the Member States, [2002] OJ C140E/538 (15 November 2001).

8 European Commission, 'Proposal for a Regulation of the European Parliament and the European Council on a Common European Sales Law’, COM (2011) 635 final, 11 October 2011.

The number of publications addressing the matter of legal integration in Europe shows no sign of abating. For helpful overviews and pertinent references, see J. Basedow, K.J. Hopt and R. Zimmermann (eds.), Max Planck Encyclopedia of European Private Law, Vol. I (2012); A. Hartkamp et al. (eds.), Towards a European Civil Code (2011); C. Twigg-Flesner (ed.), The Cambridge Companion to European Union Private Law (2010); H. Collins, The European Civil Code: The Way Forward (2008); H. Petersen et al. (eds.), Paradoxes of European Legal Integration (2008); P.-C. Müller-Graff (ed.), Gemeinsames Privatrecht in der Europäischen Gemeinschaft (1999).

10 For a critical approach, see P. Legrand, 'Antivonbar', 1 Journal of Comparative Law 13 (2006); P. Legrand, 'Against a European Civil Code', 60 Modern Law Review 4 (1997); H. Collins, 'Formalism and Efficiency: Designing European Commercial Contract Law', 8 European Review of Private Law 211 (2000); B.S. Markesinis, 'Why a Code Is Not the Best Way to Advance the Cause of European Legal Unity', 5 European Review of Private Law 519 (1997); Y. Lequette, 'Quelques remarques à propos du projet de code civil européen de M. von Bar’, Dalloz, Chron. 2202 (2002).

J. Derrida, The Other Heading, transl. by P.-A. Brault and M.B. Naas (1992), at 76 ['ce qui s'est promis sous le nom de l'Europe'] (1991). The designation of the two principal European legal traditions originates from P. Legrand, Le droit comparé (2011), at 3. The significant reception of Roman law, which need not be expressed by way of codification, constitutes a distinctive feature of the civil-law tradition. See A. Watson, The Making of the Civil Law (1981), at 4. 
The specific question that I want to address - and, which, in my view, remains largely forgotten or misunderstood by most European commentators - is that of language. Over the past years, a minority of authors, showing themselves sensitive to divergences across national languages, have expressed serious doubts regarding the possibility of achieving the intended legal and linguistic commonality within the European Union. ${ }^{12}$ Interestingly, some of the scholars who recognize the significant impact of language on the formulation of a European private law have recently claimed that a uniform understanding of the common rules cannot be expected to arise through the development of a common language but rather depends on the emergence of a common discourse.

In this paper, I question the usefulness of the concept of 'discourse' as regards the process of uniformisation of laws in Europe. First, I wish to remind European lawyers that the presence of local languages, understood as languages of tradition, must be regarded as an obstacle to the development of a European private law. Secondly, I want to establish that no recourse to discourse theory, for instance as defended by German philosopher Jürgen Habermas, can allow participants in the European project effectively to escape the inherent local character of language. Thirdly, still as part of my critical analysis, I propose to refer to Hans-Georg Gadamer's philosophical hermeneutics and Jacques Derrida's deconstruction in order to show that Habermasian discourse theory cannot be regarded as a successful vehicle for the development of a common European law.

A European private law, which is designed to replace a plurality of laws by a single law, risks failure if the purportedly uniform text translates into readings that are coloured by different national interpretive frameworks. Indeed, the European text must produce equivalent meaning throughout the Member States in order to guarantee uniform interpretation. With a view to reaching a uniform understanding of the common rules, the European task forces have been trying to elaborate a 'common terminology for jurists which overcomes jurisdictional boundaries' ${ }^{13}$ Problematically, though, many proponents of a European private-law legislation largely underestimate the impact of language on the process of uniformisation of laws. Indeed, this agenda accounts neither for language's persistence nor for its transience, two significant characteristics which in the end must defeat the very idea of a uniform law. ${ }^{14}$

First, local languages persist even as the uniform text is constructed. Given the normative character of the allegedly uniform text, each linguistic version thereof is meant to render exactly the same idea. However, it is crucial to note that two or more languages can never signify identically. To be sure, as a leading initiator of uniform law remarks, "one has to take into account the question of language at the outset, i.e., one has to act in such a way that the texts, which are first written in English, remain translatable in the different European languages' ${ }^{15}$ However, given that each national language continues to signify according to its own structures and keeps expressing its legal thought by means of a particular vocabulary, the formulation of uniform legal documents rapidly encounters its limits. ${ }^{16}$ For example, the Lando Commission retains, in the English version of Article 1:201 of its Principles of European Contract Law,

\footnotetext{
12 See R. Sacco (ed.), L'interprétation des textes juridiques rédigés dans plus d'une langue (2002); R. Sacco and L. Castellani (eds.), Les multiples langues du droit européen uniforme (1999); B. Pozzo and V. Jacometti (eds.), Multilingualism and the Harmonisation of European Law (2006); H. Claret, 'Le défi du langage (déterminabilité d'un droit européen des contrats et pluralisme juridique)', in C. QuézelAmbrunaz (ed.), Les défis de l'harmonisation européenne du droit des contrats (2012), at 47-72; S. Glanert, 'Speaking Language to Law: The Case of Europe', 28 Legal Studies 61 (2008). See, more generally, on the role of language in the current context of Europeanization and globalization of laws, S. Glanert, De la traductibilité du droit (2011).

13 Von Bar and Lando, above n. 4, at 221.

14 For a more detailed formulation of this argument, see S. Glanert (2008), above n. 12.

15 C. von Bar, 'Le groupe d'études sur un code civil européen', Revue internationale de droit comparé 127 , at 129 (2001).

${ }_{16}$ See F. Terral, 'L'empreinte culturelle des termes juridiques', 49 Meta 876, at 878 (2004).
} 
the concept of 'good faith', which is derived from Roman law. ${ }^{17}$ Even if this concept has been integrated over time in various civil-law legislations, it is, in the eyes of a common-law lawyer, simply devoid of meaning on its own terms. Indeed, the common law, emphatically not a Romanistic law, does not know bona fides - which, arguably, runs contrary to the traditional English conception of 'contract'. ${ }^{18}$ In 1992, the House of Lords thus confirmed the absence of the Roman idea in English law. According to Lord Ackner, "the concept of a duty to carry on negotiations in good faith is inherently repugnant to the adversarial position of the parties'. ${ }^{19}$ Consequently, Article 1:201 of the Lando Principles uses a formula which, for the English common-law lawyer, inevitably points to a referent bearing a distinctively local - and foreign - colour even as the expression appears in the English language. For her, to the extent that the words 'good faith' signify anything, they signify something like 'fair and open dealing', which means that they obstinately signify locally and therefore signify otherwise. ${ }^{20} \mathrm{In}$ sum, not even the Lando Commission can make the English legal language signify what it has not wanted to signify.

Another striking example of the difficulty I address is the 'penalty clause', a legal concept that is approached differently in the common-law and civil-law traditions. ${ }^{21}$ Trying to avoid what it regards as a hurdle on the path to uniformisation, the Lando Commission adopts, in Article 9:509 of its propositions for a European contract law, the notion of 'agreed payment for non-performance', long-windedly translated into French as 'clauses relatives aux conséquences pécuniaires de l'inéxecution'. ${ }^{22}$ However, contrary to the Lando Commission's expectations, a recourse to this descriptive method does not offer a way out of the problem of untranslatability because a legal language is not only the medium of a legal culture but also part of a standard language. It is not necessary to adhere to the entire Whorfian cosmology in order to appreciate that different languages, each of them interacting in a specific way with the cultural, historical and sociological 'reality', can never render a particular idea identically. ${ }^{23}$ In the case of the 'penalty clause', the concocted sequence of French words becomes a vicious circle into which semantics threatens to lose itself since each word (for example, conséquences or pécuniaires) will require to be read by reference to its 'standard' meaning within the language 'as a whole'.

Incidentally, co-writing does not constitute a remedy to the lack of equivalence across different versions of uniform law, ${ }^{24}$ as Canadian lawyers, for example, will readily appreciate on the basis of their long familiarity with bilingual legislation. In Canada, which is both a bilingual and bi-juridical country, the federal legislator, having experienced the inherent limits of legal translation for many years, finally opted in favour of the co-drafting of federal legislation in the $1970 \mathrm{~s} .{ }^{25}$ Undoubtedly, the recourse

17 For a full statement of the Principles, see O. Lando and H. Beale, Principles of European Contract Law, Vols. I and II (2000); O. Lando et al., Principles of European Contract Law, Vol. III (2003).

18 On this particular point, see G. Teubner, 'Legal Irritants: Good Faith in British Law or How Unifying Law Ends Up in New Divergences', 61 Modern Law Review 11 (1998).

19 Walford v. Miles [1992] 2 AC 128 (HL), at 138 (Lord Ackner).

20 For example, see Director General of Fair Trading v. First National Bank plc [2002] 1 AC 481 (HL), at 494 (Lord Bingham), where 'good faith' is said to mean 'fair and open dealing'. On the 'distinctively English and untranslatable' character of the word 'fair', see A. Wierzbicka, English (2006), at 141-167. For an analogous claim emphasizing the 'idiomatic' character of 'fairness' with specific reference to law, see G.P. Fletcher, Basic Concepts of Legal Thought (1996), at 81.

21 See P. Legrand, Le droit comparé, 1st ed. (1999), at 104-105.

22 For the French version of the Principles, see O. Lando (ed.), Principes du droit européen des contrats, transl. by G. Rouhette et al. (2003).

23 The principle of linguistic relativity, generally attributed to U.S. anthropologist Benjamin L. Whorf, stems from the linguistic theses of Wilhelm von Humboldt. See B.L. Whorf, Language Thought, and Reality, ed. by J.B. Caroll (1956); W. von Humboldt, The Diversity of Human Language-Structure and Its Influence on the Mental Development of Mankind, transl. by P. Heath (1988) [1836]. Over the last years, the interest in linguistic relativism has increased within linguistics and cognitive psychology. See I. Werlen, Sprachliche Relativität (2002).

${ }_{24}$ Curiously, there are still those who think of co-drafting as a solution. For example, see Lequette, above n. 10 , at 2208-2209.

${ }_{25}$ For example, see S. Šarčević, 'The Quest for Legislative Bilingualism and Multilingualism: Codrafting in Canada and Switzerland', in J.-C. Gémar and N. Kasirer (eds.), Jurilinguistique: entre langues 
to the simultaneous drafting of the French and English versions of federal statutes significantly enhanced the status of French, until then very much a minority language on the Canadian legal scene. Nevertheless, the postulate of an identity of meaning across the two linguistic versions of a federal Canadian statute has remained illusory, which is a fact that any Canadian observer will readily confirm. ${ }^{26}$ In spite of the legislator's efforts, then, no matter how energetic, local languages wish to preserve their authenticity and their integrity, that is, they persist.

This persistence also manifests itself once the uniform text is translated back into the national language, which, as must happen, entails that the text becomes the object of an interpretation by the national judge in every specific case. Those advocating a uniform European law fervently suggest that each legal notion should be understood 'independently of the detail of positive rules to which it is connected in a given law'. ${ }^{27}$ According to one of the initiators of a European private-law legislation, for example, one is 'obliged to have the courage to use words that are, on the one hand, new, and, on the other hand, easy to remember, in order to evoke immediately for every expert the right associations of ideas' ${ }^{28}$ The fact is, however, that any interpreter's understanding of any rule can only be achieved through her 'pre-understanding', that is, via an anticipatory apprehension of meaning. ${ }^{29}$ Accordingly, access to the text and to the questions arising from it is already, perhaps unconsciously, fashioned according to the historical tradition to which the interpreter belongs. A lawyer, therefore, cannot approach the uniform law in any other way than through the prism of her language, which is not an external and neutral tool but the medium of an interpretive tradition. Language, as Martin Heidegger observes, speaks 'historically', which means that, ultimately, '[t]he language speaks, not the individual' ${ }^{30}$ And the fact is that the 'effect' of history through language is not entirely transparent; it exceeds subjectivity, making understanding at once possible and limited. Thus, a judge's interpretations, for instance, are never objective, but always conditioned by the tradition that she inhabits and that inhabits her and that forms the substance of her 'pre-judgments'. The hermeneutic postulate, according to which 'one understands in a different way, if one understands at all', ${ }^{31}$ can straightforwardly be applied to the legal field. In this regard, challenges arising from the local interpretation of legal documents in a context featuring more than 20 official languages can hardly be underestimated. ${ }^{32}$ Indeed, uniform interpretation of any common private law across the different Member States within the European Union must be reckoned to be impossible.

Secondly - and somewhat paradoxically - local languages harbour a transience which shows itself to be another insuperable obstacle on the path to the uniformisation of laws. The problem arises from the fact that no uniform law can be created ex nihilo. In the specific case that interests us, it must be grounded in national legislation, caselaw and scholarship on the basis of studies undertaken by lawyers originating from all Member States within the European Union. Now, for practical and economic reasons,

et droits (2005), at 277-292; R. Leckey and A. Braën, 'Legislation and Bilingualism', in M. Bastarache (ed.), Language Rights in Canada, 2nd ed. (2004), at 37-139; L.A. Levert, 'La cohabitation du bilinguisme et du bijuridisme dans la législation fédérale canadienne: mythe ou réalité?', 3 Revue de la common law en français 127 (2000); L.-P. Pigeon, 'La rédaction bilingue des lois fédérales', 13 Revue générale de droit 177 (1982).

26 See Glanert (2011), above n. 12, at 238-247.

27 G. Rouhette et al., 'Note sur la version française', in O. Lando (ed.), Principes du droit européen des contrats, transl. by G. Rouhette et al. (2003), at 47-49 (48).

28 C. von Bar, 'Le groupe d'études sur un code civil européen', 53 Revue internationale de droit comparé 127, at 136 (2001) (emphasis added).

29 See H.-G. Gadamer, Truth and Method, transl. by J. Weinsheimer and D.G. Marshall (1989), at 268-382 [1960]. A critical analysis of Gadamer's idea of 'pre-understanding' is offered by H.-H. Kögler, The Power of Dialogue, transl. by P. Hendrickson (1996), at 19-110. I address this argument at greater length in the third part of this paper. See below.

30 M. Heidegger, The Principle of Reason, transl. by R. Lilly (1991), at 96 ['geschichtlich'/ (d)ie Sprache spricht, nicht der Mensch'] (1957).

31 Gadamer, above n. 29, at 296 (emphasis original) (I have modified the translation).

32 See S. Šarčević, 'Problems of Interpretation in an Enlarged European Union', in R. Sacco (ed.), L'interprétation des textes juridiques rédigés dans plus d'une langue (2002), at 239-272. 
English has become the quasi-exclusive working language of the different task forces. ${ }^{33}$ Although the Lando Commission first agreed on the use of two different working languages, this bilingualism was rapidly abandoned in favour of English. ${ }^{34}$ For its part, the Study Group on a European Civil Code gave preference to English from the start. ${ }^{35}$ Professor von Bar advances different arguments in order to justify this choice. There did not seem to be another European language in which all participants could effectively communicate or on which they would agree as a second official language. Further, simultaneous translation was considered to be obstructive in terms of the 'natural' course of discussions and regarded as too expensive in any event. However, it is possible that the particular attraction of English in comparison to French, for example, exceeded the proposed practical justifications: 'Whereas the United States embody, on a mythical level, an egalitarian modernity that is politically, economically, and culturally strong, moreover reinforced by the memory of the immigrant as artisan of his own existence', 'the French language refers to political and economic forms that are perceived as outdated and to cultural forms that pertain to nostalgia', which 'could perhaps explain in part why it has lost some of its attraction' ${ }^{36}$ In addition, the decision of the Lando Commission and of the Study Group on a European Civil Code to make English the dominant working language reflects a general European movement. For instance, the European Commission, one of the most productive European institutions, formulates the majority of its primary texts in English. This strategy, which stands in stark contrast to the officially proclaimed multilingualism, shows the ever-growing informal presence of English at all levels of the European construction. ${ }^{37}$ Inevitably, the decision by the various task forces to make English the principal means of communication has set in motion an immense translation process which cannot but have significant implications. The supremacy of one language over all others indeed stultifies the very idea of 'uniformisation'.

In practice, the recourse to English as a working language compels most of the participants in the various task forces to operate in a foreign tongue and thus to relinquish their native language. In effect, each lawyer is expected to explain her national law to all the other members of her working group. Given the multiplicity of languages around the table, this account, in the name of efficient communication, can only take place in a common working language, that is, in English. Concretely, the Italian lawyer, for example, in order to elucidate the present state of Italian law with respect to a particular legal problem, must therefore translate the Italian legal rules and principles into the common working language. In the same way, her German colleague, who wants to describe the German point of view with regard to a specific question, is constrained to express the German legal ideas in the English language. Once the different national legal solutions have been translated into the working language, further discussions will generally take place in English. ${ }^{38}$ Thus, English, reduced to a strictly utilitarian function,

\footnotetext{
33 Id., at 192.

34 See Rouhette et al., above n. 27, at 48.

35 See C. von Bar, 'Des principes à la codification: perspectives d'avenir pour le droit privé européen', 33 Les Annonces de la Seine 4 (2002).

36 M. Laffitte, 'Quelques hypothèses sur la place du français et de l'anglais dans le monde actuel ...', in R. Chartier and P. Corsi (eds.), Sciences et langues en Europe (1996), at 198 ['(A)lors que les EtatsUnis incarnent, sur un plan mythique, une modernité égalitaire, politiquement, économiquement et culturellement forte, renforcée de surcroît par le souvenir de l'immigrant, artisan de sa propre existence' / 'la langue française renvoie à des formes politiques et économiques perçues comme périmées, et à des formes culturelles qui relèvent de la nostalgie' / 'pourrait (...) partiellement expliquer pourquoi elle a perdu une partie de sa séduction'].

37 See C. Truchot, 'Languages and Supranationality in Europe: The Linguistic Influence of the European Union', in J. Maurais and M.A. Morris (eds.), Languages in a Globalising World (2003), at 100-105. The predominance of the English language is particularly criticized by French lawyers. See A. Supiot, 'Communiquer ou se comprendre?' in F. Nies (ed.), Europa denkt mehrsprachig (2005), at 153-163.

38 Given the fact that the debates taking place within the working groups influence the choice of rules and principles for a uniform private law, the following questions arise: Who are the translators? Do all those who participate in the uniformisation process speak sufficiently and equally well the English language and the English legal language? Is the German, French, Italian, Spanish or Dutch lawyer aware of the cultural specificity of the English (legal) terms, which can be of British, US or Australian origin, and which, on
} 
turns into a simple means of communication. Along the way, local languages, to be understood as 'traditional language[s]' - not only in the sense of 'mere passing in' but also as 'the safeguarding of the new possibilities of the already spoken language' 39 fade away before English: they become transient. It remains, though, that even as local languages are made to efface themselves before a single language - English - the latter can only imperfectly substitute for them. Indeed, although the English language acts as the 'working' representative of local languages, it cannot but conduct its mission in a deficient manner. Arguably, its ability faithfully to represent - in the way every language does - is even more limited than usual because it is made to convey all at once what the French, German, Italian, Portugese, Spanish and other European Union languages are meant to say, which is evidently more than it can accomplish such that participants have to accept unavoidable linguistic modifications happening along the way.

The designation of English as the dominant working language reflects a general, if unexamined, view prevailing in the different groups according to which law and language can be separated. This assumption would entail that, for example, French law is not 'necessarily' or 'exclusively' bound to the French language, but can also be made intelligible in other languages such as English. ${ }^{40}$ Of course, one can salute the tenets underlying such an approach as it postulates communicability between individuals from different linguistic or cultural communities and holds that a language does not constitute an isolated unit standing apart from other languages because of its lexical and grammatical particularities. The disconcerting hypothesis of colliding soliloquies is thus excluded. Yet, it must be seen that the operational premise partakes of wishful thinking.

In this regard, though one may recall Walter Benjamin, who in his famous essay speaks about the languages' determination to translate each other, ${ }^{41}$ it remains that the division of 'reality' is not identical from one language to another as the usual translation of the Spanish term bosque by the German word Wald illustrates very clearly. ${ }^{42}$ Would it not be utopian to believe that a bosque signifies to a Spaniard what a Wald means to a German? In fact, a Spaniard associates bosque with a location featuring even only a few trees, whereas a German thinks of a Wald as a sizeable terrain with a large number of trees. The difference at the level of the signified can readily be explained by the fact that in Germany the tree-covered area is a lot larger than in Spain. A second example similarly demonstrates the inevitable divergences between languages that are continually developing in different cultural contexts. How should one translate the French chaumiere into the Italian language, when it does not correspond either to a capanna, suggesting a wooden construction, or to a casetta, referring to a house with a tiled roof, and even less to a baita, designating a crude temporary refuge in the mountains? Even the words casupol[a] in pietra, although they emphasize the stone structure, still do not convey the idea of the thatched roof, a key characteristic of the chaumière. ${ }^{43}$

Let us now transfer the problem to speech communities within languages in order to become more aware of its magnitude. Does the word Wald evoke equivalent images for a worker of the industrial Ruhr and a farmer of the 'mythical' Black Forest? Does the term chaumière connote identical feelings in today's French youth and their grandparents? If one applies José Ortega y Gasset's philological formulation to translation, one can see that, on the one hand, 'each expression is deficient' because it does not say everything that one wants to say, and that, on the other hand, 'each expression is exuberant',

account of English being the working language, she must use in order to explain a specific aspect of her own legal culture?

39 M. Heidegger, 'Traditional Language and Technological Language', transl. by W. Torres Gregory, 23 Journal of Philosophical Research 129, at 142 (1998) ['überlieferte Sprache' / 'bloße Weitergabe' / 'Verwahrung neuer Möglichkeiten der schon gesprochenen Sprache'] [1989].

40 N. Kasirer, 'Lex-icographie mercatoria', 47 American Journal of Comparative Law 653, at 659 (1999).

41 See W. Benjamin, 'The Task of the Translator', transl. by H. Zohn, in W. Benjamin, Selected Writings, ed. by M. Bullock and M.W. Jennings, Vol. I (1996), at 253-263 [1923].

42 See J. Ortega y Gasset, 'Miseria y esplendor de la traducción', in Obras completas, Vol. V (1983), at 436 [1937].

${ }_{43}$ See U. Eco, Experiences in Translation, transl. by A. McEwen (2001), at 48-49. 
because it says more than one intends to say. ${ }^{44}$ Now, 'deficiency' and 'exuberance' are inherent, structural features of language. One of the most influential theoretical contributions to translation studies explains that 'any language [...] encompasses within itself a single system of ideas which, precisely because they are contiguous, linking and complementing one another within this language, form a single whole - whose several parts, however, do not correspond to those to be found in comparable systems in other languages'. ${ }^{45}$

There is no reason for lawyers to suppose that law would somehow be immune from language's limitations. To the same extent that the words droit commun cannot render the legal 'reality' as it is expressed through the terms 'common law', the forms 'private law' and 'public law' cannot account for the French legal landscape where the matter is about droit privé and droit public. While translation mechanically puts words opposite their lexical correspondents, the fact is that 'simple words are not yet wordly' so that the 'word for word' does not ultimately constitute 'fidelity to the word' ${ }^{46}$ This is to say that 'through translation, the work of thought finds itself transposed into the spirit of another language and suffers an inevitable transformation ${ }^{47}$ The challenge of translation can helpfully be described as follows: 'In order to transport a single word without distortion, one would have to transport the entire language around it. ${ }^{48}$ Further, '[i]n order to translate a language, or a text, without changing its meaning, one would have to transport its audience as well', ${ }^{49}$

But let us return to the European task forces operating in English. Given that the law expressed in a particular working language can only be subordinated to the representations that this working language allows, and because no language admits of an unlimited number of worldviews, as any serious translator fully appreciates, the obligatory passage through a working language leads the laws as expressed in the national languages to undergo significant and irreversible mutations. How can the French lawyer faithfully explain French law in English or how can the Portuguese lawyer loyally explain Portuguese law in English? How can the French lawyer engage a negotiation with Portuguese law, as is required within the process of uniformisation of laws, when the English translation of this Portuguese law only delivers an inadequate image of it? And how could the Portuguese lawyer enter into a negotiation with French law when such French law is rendered through the intrinsic limits of the English language? Jacques Derrida aptly stresses that 'there is no translatological meta-language, which, as an idiom, would not be subjected to the drama that it claims to be formalizing or translating in its turn'. ${ }^{50}$ Consequently, local languages - and local laws - are compelled to efface themselves before the common working language even as the very fact of this relegation subverts any attempt at uniformisation. The English language simply cannot bring together, in a manner that would be uniform, a diverse collection of local languages and laws.

Both because local languages in fact show themselves resisting any attempt at elimination on the part of uniformisers of law and because no single language can actually hope loyally to merge an array of local languages within a 'uniformity', any claim that a uniform law can satisfactorily be stated must be seen as unconvincing. I

\footnotetext{
44 J. Ortega y Gasset, 'La reviviscencia de los cuadros', in Obras completas, Vol. III (1983), at 439 ['Todo decir es deficiente' / 'Todo decir es exuberante'] (1946).

45 F. Schleiermacher, 'On the Different Methods of Translating', transl. by S. Bernofsky, in L. Venuti (ed.), The Translation Studies Reader, 2nd ed. (2004), at 59-60 ['jede Sprache (enhält) (...) ein System von Begriffen in sich, die eben dadurch daß sie sich in derselben Sprache berühren, verbinden, ergänzen, ein Ganzes sind, dessen einzelnen Theilen aber keine aus dem System anderer Sprachen entsprechen'] [1813]. 46 M. Heidegger, 'Heraklit', in Gesamtausgabe, Vol. LV (1994), at 44 ['bloße Wörter sind noch keine Worte' / 'wörtlich' / '(w)ortgetreu'] (1979). To my knowledge, these lectures given in 1943-1944 have not yet been translated into English.

${ }_{47}$ M. Heidegger, 'Prologue [to Qu'est-ce que la métaphysique?]', in Questions I et II, transl. by H. Corbin (1968), at 10 ['Par la traduction, le travail de la pensée se trouve transposé dans l'esprit d'une autre langue, et subit ainsi une transformation inévitable'] (1938). Heidegger wrote this text for the French translation of his inaugural lecture at the University of Freiburg, entitled Was ist Metaphysik? delivered on 24 July 1929.

48 E. Hoffman, Lost in Translation (1991), at 272.

49 Id., at 273.

50 J. Derrida, 'Fidélité à plus d'un', 13 Cahiers Intersignes 223 (1998).
} 
now turn to consider a view suggesting that what I regard as the unsurpassable impact of language on uniformisation of law within the European Union could be circumvented after all.

In a paper published in 2004, Anne Lise Kjær, a professor and specialist in legal linguistics at the University of Copenhagen, argues that 'what is common, is not the language of the European legal actors, but their discourse about European law'. ${ }^{51}$ As I read them, authors such as Kjær, who endorse the emergence of a common legal discourse within the European Union, assume that it is possible to escape from grammatical, lexical and semantic divergences across national languages so that communication hurdles between lawyers from different cultural backgrounds can be overcome. Thus, Ana López-Rodríguez, a professor of law at the University of Aarhus, insists that '[w]ithin a common legal discourse, even linguistic diversity will be a minor problem' ${ }^{52}$

Of course, the threshold question arises as to how a common legal discourse can be generated within the European Union. According to López-Rodríguez, who makes her point somewhat tentatively, '[t]he European legislator should [...] promote the development of a common European legal discourse through legal research, legal education and the gradual creation of a common legal methodology. Ultimately, a common legal culture may crystallize, thereby facilitating the achievement of real uniformity' ${ }^{53}$ For her part, Kjær seems more optimistic as she stresses that ' $[\mathrm{w}]$ hen legal discourse becomes international, when legal argumentation is no longer confined to the national legal system, when actors enter into an international interpretive community, the foundation is laid for a change of meaning of national legal concepts reflecting what is experienced in an international, cross-cultural discourse on law'. ${ }^{54}$

Interestingly, the idea of a common discourse within the European Union, such as is advocated by scholars like Kjær and López-Rodríguez, finds significant support in the theories developed by Jürgen Habermas, an influential German philosopher and sociologist. Habermas, commonly regarded as the most famous representative of the second generation of the so-called 'Frankfurt School', indeed defends a theory of society articulated around the act of communication apprehended as emphasizing the emancipatory capacities of human reason. In his major work, The Theory of Communicative Action (Theorie des kommunikativen Handelns), Habermas envisages a situation in which different individuals, all capable of speaking and acting, are in search of a consensus allowing them to coordinate their endeavours. ${ }^{55}$ In Habermas's social configuration, language plays a preeminent role. According to him, 'the communicative model of action presupposes language as a medium of uncurtailed communication whereby speakers and hearers, out of the context of their preinterpreted lifeworld, refer simultaneously to things in the objective, social, and subjective worlds in order to negotiate common definitions of the situation' ${ }^{56}$ However, can individuals who do not share the same lifeworld - which is arguably the case for nationals of the different Member States within the European Union - be in a position to operate 'simultaneously', as Habermas would have it, that is, effectively to communicate with each other? In particular, one has to ask if national languages must not be regarded as an obstacle to

\footnotetext{
51 A.L. Kjær, 'A Common Legal Language in Europe', in M. Van Hoecke (ed.), Epistemology and Methodology of Comparative Law (2004), at 397.

52 A.M. López-Rodríguez, 'Towards a European Civil Code Without a Common European Legal Culture? The Link Between Law, Language and Culture', 29 Brooklyn Journal of International Law 1195, at 1220 (2003).

53 Id., at 1214.

54 Kjær, above n. 51, at 394.

55 See J. Habermas, The Theory of Communicative Action, 2 Vol., transl. by T. McCarthy (1984) [1981].

56 See Id., Vol. I, at 95 ['das kommunikative Handlungsmodell setzt Sprache als ein Medium unverkürzter Verständigung voraus, wobei sich Sprecher und Hörer aus dem Horizont ihrer vorinterpretierten Lebenswelt gleichzeitig auf etwas in der objektiven, sozialen und subjektiven Welt beziehen, um gemeinsame Situationsdefinitionen auszuhandeln'].
} 
communication for people originating from different cultural communities - a matter which connects to the larger issue regarding the feasibility of Habermas's injunction that individuals should move 'out of the context of their preinterpreted lifeworld'.

Though Habermas does not appear specifically to challenge Wilhelm von Humboldt's thesis pursuant to which each local language carries a particular worldview, he vigorously defends the idea that human beings are not confined to a given worldview because of the language they speak. Indeed, Habermas postulates that communication between individuals can succeed - that a common discourse is possible - despite the existence of a diversity of languages and an array of pre-existing interpretive backgrounds. According to Habermas, "[e]ven in the most difficult processes of reaching understanding, all parties appeal to the common reference point of a possible consensus, even if this reference point is projected in each case from within their own contexts' ${ }^{57}$ Although, concessio non dato, the possibility of a common discourse between persons speaking different languages might be regarded as desirable, it is difficult to understand to what extent, if at all, individuals hailing from different linguistic communities can share what Habermas calls 'the common reference point of a possible consensus'. I discern three significant problems arising from the use of Habermasian discourse theory as applied to the context of legal integration within the European Union.

First, the very concept of 'discourse' is not clearly defined and, perhaps, is not clearly definable. There is simply no consensus among scholars working in the fields of linguistics and social sciences as regards the meaning to be given to the term 'discourse'. In effect, every discourse theory is someone's discourse theory. Although difficulties arising from such semantic indeterminacy are obviously not specific to discourse theory, they seem to be raising a particularly significant hurdle in this instance. Is it not problematic indeed that the defenders of discourse theory should be advocating the possibility of consensual communication when they themselves appear unable to reach a consensus as regards the meaning of 'discourse'?

Secondly, every discourse requires the use of language. Evidently, individuals who wish to join in a discourse must make use of a given language. And if the participants in the discourse come from different cultural backgrounds, as is the case within the European Union, more than one language will have to be mobilized. In fact, the discourse at issue becomes more and more complex with each additional language. In other words, scholars who advocate the development of a common discourse in a transnational situation cannot escape the challenges raised by translation. The fact is that no translation can feature an equivalence across languages. Indeed, it is not that translation constructs equivalence out of difference but that it formulates difference out of incommensurability. ${ }^{58}$ The ensuing impossibility of communication across languages is captured by Martin Heidegger in a statement which strikes me as being as powerful as it is economical: '[L]anguage is monologue. ${ }^{59}$

Thirdly, inasmuch as it inescapably features an object, a discourse requires a local act of interpretation and application. Suppose two European lawyers engaging in a conversation having as its object the concept of 'human rights'. The interpretations that will be propounded of the concept of 'human rights', as these lawyers earnestly pursue their discussion, will inevitably call upon relevant cultural values, for example religious beliefs or ideological commitments, which cannot but manifest themselves as forms of local knowledge. Now, the embeddedness in local knowledge of the understandings of human rights at issue would appear to preclude the emergence of a common discourse, which assumes the possibility of surpassing localism and the further possibility of bridging localisms.

In the context of my critical engagement with Habermas's theory of communicative action with respect to current European legal initiatives, I find it helpful to rely on HansGeorg Gadamer's philosophical hermeneutics and Jacques Derrida's deconstruction in

J. Habermas, Postmetaphysical Thinking, transl. by W.M. Hohengarten (1993), at 138 ['Noch im schwierigsten Verständigungsprozeß stützen sich alle Parteien auf den gemeinsamen, wenn auch jeweils aus dem eigenen Kontext heraus entworfenen Bezugspunkt eines möglichen Konsenses'] (1988).

58 I draw on M. Morris, 'Foreword', in N. Sakai, Translation and Subjectivity (1997), at xiii.

59 M. Heidegger, On the Way to Language, transl. by P.D. Hertz (1971), at 134 ['die Sprache ist Monolog'] (1959). 
order to show that there are no reliable criteria allowing us to conclude that individuals can in fact reach a discursive consensus, which is perhaps another way of saying that any discourse will persistently be informed by the language, not to mention the culture, to which a speaker belongs. ${ }^{60}$

In 1960, Hans-Georg Gadamer released his Truth and Method (Wahrheit und Methode), which purports to offer a fully fledged theory of modern hermeneutics. ${ }^{61}$ While Gadamer's text is widely regarded as the most important contribution to German philosophy since Martin Heidegger's Being and Time (Sein und Zeit), ${ }^{62}$ it seems fair to say that, with some noteworthy exceptions ${ }^{63}$ his work remains under-appreciated in the academic world outside of Europe, including in the United States. Still, Gadamer's thoughts on hermeneutics have exercised a crucial influence on a wide range of academic fields, namely, art theory, history, literary theory, philosophy, psychology, religious studies and sociology. ${ }^{64}$ More recently, perhaps taking their cue from Gadamer himself who refers to ' $[\mathrm{t}]$ he exemplary significance of legal hermeneutics', ${ }^{65}$ some scholars have been underlining the role of philosophical hermeneutics for the study of law. ${ }^{66}$

In Gadamer's words, '[hermeneutics'] work is not to develop a procedure of understanding, but to clarify the conditions in which understanding takes place. However, these conditions do not amount to a 'procedure' or method which the interpreter must of himself bring to bear on the text; rather, they must be given. The prejudices and foremeanings that occupy the interpreter's consciousness are not at his free disposal. ${ }^{67} \mathrm{In}$ sum, '[u]nderstanding is, essentially, a historically effected event' ${ }^{68}$ To make the point even more emphatically, Gadamer claims that ' $[u]$ nderstanding is to be thought of less as a subjective act than as participating in an event of tradition' ${ }^{69}$ Gadamer thus argues that every understanding is to be apprehended as an 'event', a happening of sense that can never be grasped by any method. He maintains the need to underscore "not what we do or what we ought to do [which would be a methodical concern], but what happens

\footnotetext{
60 For a more detailed discussion of Gadamer's and Derrida's thoughts on interpretation in the context of comparative legal studies, see S. Glanert, 'Method?', in P.G. Monateri (ed.), Methods of Comparative Law (2012), at 70-79.

61 Gadamer, above n. 29.

62 See, for example, J.C. Weinsheimer, Gadamer's Hermeneutics (1985); G. Warnke, Gadamer: Hermeneutics, Tradition and Reason (1987); J. Grondin, Einführung in die philosophische Hermeneutik (2001); J. Malpas, U. Arnswald and J. Kertscher (eds.), Gadamer's Century (2002); N. Davey, Unquiet Understanding: Gadamer's Philosophical Hermeneutics (2006); B. Krajewski (ed.), Gadamer's Repercussions (2004); J. Malpas and S. Zabala (eds.), Consequences of Hermeneutics: Fifty Years After Gadamer's Truth and Method (2010); D. Di Cesare, Gadamer: Ein philosophisches Porträt (2009).

63 See, for example, R. Rorty, The Linguistic Turn (1992). Rorty's indebtedness to Gadamer is expressed in many of his books.

${ }_{64}$ Out of many applications, see, for example, N. Davey, 'Hermeneutics and Art Theory', in P. Smith and C. Wilde (eds.), A Companion to Art Theory (2002), at 436-447; G. Warnke, 'Sex, Gender, and Hermeneutics', in J. Malpas and S. Zabala (eds.), Consequences of Hermeneutics: Fifty Years After Gadamer's Truth and Method (2010), at 324-342; E.R. Saks, Interpreting Interpretation: The Limits of Hermeneutic Psychoanalysis (1999).

65 Gadamer, above n. 29, at 321 ['Die exemplarische Bedeutung der juristischen Hermeneutik'].

66 See, for example, G. Leyh (ed.), Legal Hermeneutics (1991); F.J. Mootz III (ed.), Gadamer and Law (2007).

67 Gadamer, above n. 29, at 295 ['ihre Aufgabe (ist) überhaupt nicht (...), ein Verfahren des Verstehens zu entwickeln, sondern die Bedingungen aufzuklären, unter denen Verstehen geschieht. Diese Bedingungen sind aber durchaus nicht alle von der Art eines 'Verfahrens' oder einer Methode, so daß man als der Verstehende sie von sich aus zur Anwendung zu bringen vermöchte - sie müssen vielmehr gegeben sein. Die Vorurteile und Vormeinungen, die das Bewußtsein des Interpreten besetzt halten, sind ihm als solche nicht zu freier Verfügung'].

68 Id., at 299 ['Verstehen ist seinem Wesen nach ein wirkungsgeschichtlicher Vorgang'] (emphasis in the English translation).

69 Id., at 291 ['Das Verstehen ist selber nicht so sehr als eine Handlung der Subjektivität zu denken, sondern als Einrücken in ein Überlieferungsgeschehen'].
} 
to us over and above our wanting and doing'. ${ }^{70}$ In asserting that 'we should learn to understand ourselves better and recognize that in all understanding, whether we are expressly aware of it or not, the efficacy of history is at work', ${ }^{71}$ and in claiming in the most forceful terms that 'a naive faith in scientific method' can lead to 'an actual deformation of knowledge' ${ }^{72}$ Gadamer's philosophical investigation revolutionizes the traditional view of hermeneutics aiming for the formulation of a method which would unproblematically lead to understanding.

The focus of interpretation, such as a text, makes affirmations or raises questions that invite the interpreter to respond. According to Gadamer, 'a person trying to understand a text is prepared for it to tell him something, ${ }^{73}$ Acts of interpretation are therefore dialogical in the sense that they entail a ceaseless conversation between the tradition and the interpreter. As the dialogue progresses, the interpreter revises his prejudices, rethinks his questions and expects new answers. The text, that is, the partner in dialogue, 'if it is to be understood properly - i.e., according to the claim it makes - must be understood at every moment, in every concrete situation, in a new and different way'. ${ }^{74}$ Yet, Gadamer, using the concept of 'effective history' (Wirkungsgeschichte) to convey the historicality of all understanding, shows that it is impossible for the interpreter to transport herself into a horizon different from her own. Indeed, Gadamer refers to 'historically-effected consciousness' (wirkungsgeschichtliches Bewußtsein) as a mode of being that is sensitive to its own historical situatedness. Historically effected consciousness knows that ' $[\mathrm{t}] \mathrm{o}$ try to escape from one's own concepts in interpretation is not only impossible but manifestly absurd' ${ }^{75}$ For example, a lawyer cannot apprehend a text, a situation or a person in any other way than through the prism of her language, which is not an external and neutral tool but the medium of an interpretive tradition. As Gadamer notes, '[v]erbal form and traditionary content cannot be separated in the hermeneutic experience' ${ }^{76}$ Thus, the lawyer's discourse is always conditioned by the tradition that she inhabits and that inhabits her and forms the substance of her 'pre-judgments'.

In other words, the historically effected consciousness appreciates that, since history is incessantly at work in all understanding, whether one is actually aware of it or not, such understanding is itself shaped by historical tradition. It is therefore impossible for an individual to find an Archimedean standpoint from which she could look at herself or at her culture. For Gadamer, 'the illumination of [the hermeneutic] situation - reflection on effective history - can never be completely achieved; yet the fact that it cannot be completed is due not to a deficiency in reflection but to the essence of the historical being that we are. To be historically means that knowledge of oneself can never be complete' ${ }^{77}$ It follows that ' $[\mathrm{t}] \mathrm{he}$ focus of subjectivity is a distorting mirror' ${ }^{78}$ And, understanding being grounded in tradition, no method can ensure that understanding of a text, or of a situation, will be achieved. In the end, because "we are already finding ourselves in the middle of the game and can occupy no neutral standpoint - even if we

\footnotetext{
70 Id., at xvi ['Nicht was wir tun, nicht, was wir tun sollten, sondern was über unser Wollen und Tun hinaus mit uns geschieht, steht in Frage'].

${ }_{71}$ Id., at 300 ['daß man sich selber richtiger verstehen lerne und anerkenne, daß in allem Verstehen, ob man sich dessen ausdrücklich bewußt ist oder nicht, die Wirkung dieser Wirkungsgeschichte am Werke ist'].

72 Id. ['d(ie) Naivität des Methodenglaubens' / 'eine tatsächliche Deformation der Erkenntnis'].

73 Id., at 271 ['Wer einen Text verstehen will, ist vielmehr bereit, sich von ihm etwas sagen zu lassen. Daher muß ein hermeneutisch geschultes Bewußtsein für die Andersheit des Textes von vornherein empfänglich sein'].

74 Id., at 307-308 ['wenn er angemessen verstanden werden soll, d. h. dem Anspruch, den der Text erhebt, entsprechend, (dann muß er) in jedem Augenblick, d. h. in jeder konkreten Situation, neu und anders verstanden werden'].

75 Id., at 398 ['Die eigenen Begriffe bei der Auslegung vermeiden zu wollen, ist nicht nur unmöglich, sondern offenbarer Widersinn'].

76 Id., at 438 ['Sprachliche Form und überlieferter Inhalt lassen sich in der hermeneutischen Erfahrung nicht trennen'].

77 Id., at 301 ['die Erhellung dieser (hermeneutischen) Situation, d. h. die wirkungsgeschichtliche Reflexion, ist nicht vollendbar, aber diese Unvollendbarkeit ist nicht ein Mangel an Reflexion, sondern liegt $\mathrm{im}$ Wesen des geschichtlichen Seins, das wir sind. Geschichtlichsein heißt, nie im Sichwissen aufgehen'].

78 Gadamer, above n. 29, at 278 ['Der Fokus der Subjektivität ist ein Zerrspiegel'].
} 
strive very hard for objectivity and put our prejudices at risk' ${ }^{79}$ the gist of the matter is, once again, that 'we understand in a different way, if we understand at all' ${ }^{80}$ Despite Gadamer's overall philosophical project often being branded as unduly conservative, ${ }^{81}$ his views on the historical situatedness of the interpreter are echoed in more radical circles. Still, there are those, such as Jacques Derrida, who felt that Gadamer simply did not take critique far enough.

Arguably, the French philosopher having had the most impact on $20^{\text {th }}$-century intellectual life (in 1998, the New York Times referred to him as 'perhaps the world's most famous philosopher - if not the only famous philosopher'), ${ }^{82}$ Derrida addressed a wide range of subjects. In the course of a writing career spanning more than 40 years, he released twice as many books, most of them translated in any number of languages, engaging such varied themes as painting, friendship, religion and sovereignty, not to mention photography, psychoanalysis, archival work and the gift. Derrida's abiding concerns, though, always had to do with texts and with the reading of texts. In this regard, Derrida's name is closely associated with 'deconstruction' - an interpretive/political challenge to philosophical systems anchored to a close reading and dismantling of texts dedicated to showing that the purportedly foundational terms on which texts are claimed to rest are, in effect, the product of exclusive disjunctions, that is, of crucial choices accompanied by a marginalization or a suppression of other discourses which are inherent to the text itself, to whose summons deconstruction responds and which deconstruction affirms (as opposed, say, to injecting them into the text). Through the valorization of these other discourses, deconstruction ultimately seeks to redeem otherness and, in the process, to further hospitality and justice. When pressed to explicate deconstruction, Derrida replied with a brief formula meant to capture this basic gesture of heteronomic commitment: '[P]lus d'une langue, that is, both more than a language and no more of $a$ language. ${ }^{83}$ Deeply indebted to Edmund Husserl's phenomenology and to Martin Heidegger's 'correction', Derrida insists on the historicity and on the linguisticality of human understanding. He thus argues that a philosophical system cannot rest on some foundational justification or necessity. While a philosophical framework is made to seem natural, it inevitably depends on the dogmatist's predilections. In sum, deconstruction diagnoses and exploits the illusion generated by theories projecting themselves as selfevident or the fact of their idealization by the thinking theorist. ${ }^{84}$

As regards his views on interpretation, Derrida's philosophical enterprise is very much at odds with Gadamer's, which their 1981 encounter (or, rather, non-encounter) at

\footnotetext{
H.-G. Gadamer, The Beginning of Philosophy, transl. by R. Coltman (2000), at 30 ['wir (befinden) uns schon mitten im Spiel (...) und (nehmen) keinen neutralen Blickpunkt ei(n) - auch wenn wir uns noch so sehr um Objektivität bemühen und unsere Vorurteile aufs Spiel setzen'] [1996[.

80 Id., at 296 ['man anders versteht, wenn man überhaupt versteht'].

81 This charge is frequently expressed. While applauding Gadamer's critique of positivism and of positivism's scientifistic devaluation of understanding, Habermas, for example, claims that philosophical hermeneutics gives short shrift to ideology and power and, specifically, fails to account for the way in which tradition can betray the effects of coercion on understanding. See J. Habermas, On the Logic of the Social Sciences, transl. by S.W. Nicholsen and J.A. Stark (1988), at 143-170 [1977]; J. Habermas, 'The Hermeneutic Claim to Universality', transl. by J. Bleicher, in J. Bleicher (ed.), Contemporary Hermeneutics: Hermeneutics As Method, Philosophy and Critique (1980), at 181-211 [1977].

82 D. Smith, 'Philosopher Gamely in Defense of His Ideas', The New York Times, 30 May 1998, <www. nytimes.com/1998/05/30/arts/philosopher-gamely-in-defense-of-his-ideas.html> (accessed on 10 August 2012).

83 J. Derrida, Memoires for Paul de Man, rev'd Eng. ed., transl. by C. Lindsay (1989), at 15 (1988). The words 'plus d'une langue' appear in French in the English text and the periphrasis is added to the English version.

${ }_{84}$ The number of books devoted to Derrida's thought is beyond recension. See, for helpful introductions in Derrida's own words with particularly useful accompanying commentaries, J. Derrida and M. Ferraris, A Taste for the Secret, ed. by G. Denis and D. Webb, transl. by G. Denis (2001) [1997]; J.D. Caputo (ed.), Deconstruction in a Nutshell: A Conversation with Jacques Derrida (1997). See also, for lengthier yet accessible readings, J.H. Miller, For Derrida (2009); S.M. Wortham, The Derrida Dictionary (2010). See, generally, for appreciations of Derrida's impact, T. Cohen (ed.), Jacques Derrida and the Humanities (2001); P. Goodrich et al. (eds.), Derrida and Legal Philosophy (2008); P. Legrand (ed.), Derrida and Law (2009).
} 
the Goethe-Institut in Paris illustrated to somewhat striking effect. ${ }^{85}$ Not only is Derrida not prepared to defer to tradition (in the way in which Gadamer appears willing to do), but he also expresses outright his intention to subvert what he regards as a 'hermeneutic veil' ${ }^{86} \mathrm{He}$ wishes to 'perforate' it ${ }^{87}$ to undermine its 'colonial structure', ${ }^{88}$ 'to withdraw [interpretation] from any hermeneutic question assured of its horizon', 89 'to rout all the Schleiermachers, all the veilmakers' ${ }^{90}$ Over against Gadamer's philosophical hermeneutics, Derrida holds that a text is inherently and insurpassably indebted to grammatical ambiguity, to syntaxic instability and to semantic indecidability. $\mathrm{He}$ emphasizes that 'equivocity is, in fact, always irreducible', because 'words and language in general are not and can never be absolute objects'. ${ }^{91}$ Accordingly, there cannot be, properly speaking, anything like the meaning of a text. Indeed, the very fabric of a text opposes the idea of a meaning that would be its true meaning: 'A thousand possibilities will always remain open. ${ }^{, 92}$

Now, for Derrida, the inaccessibility of a text - the unreachability of something that would emerge, clearly, uncontrovertibly, as the meaning of a text - must be apprehended as beneficial. While, according to Gadamer, 'whatever is alienating in a text, whatever makes the text unintelligible, is to be overcome and thereby cancelled out by the interpreter', ${ }^{93}$ such that its 'real meaning' becomes available,${ }^{94}$ Derrida takes the view that there is always something that the interpreter cannot access, something remaining, 'an irreducible remainder or excess ${ }^{95}$ - the text's secret, if you will. And it is good that there should be this distance between the interpreter and the text. Indeed, it is precisely this discontinuity which allows the conversation about the text to continue. For example, it is because interpreters have not yet managed to produce anything like the meaning of Romeo and Juliet that discussions, interventions and debates about the play continue to flourish, which Derrida regards as beneficial. If, to return to Gadamer, whatever is unintelligible about the play had been overcome, the conversation would have stopped a long time ago. It is only because understanding is, in effect, interrupted, because instead of understanding there is non-understanding, because the text resists appropriation through interpretation, that there is ongoing interest in the text, that it survives as a focus of interpretive interest. Derrida thus calls for the '[e]radication of the hermeneutic principle' inasmuch as it constitutes an enterprise aiming for 'interpretive totalization'. ${ }^{96}$

\footnotetext{
See D.P. Michelfelder and R.E. Palmer (eds.), Dialogue and Deconstruction: The Gadamer-Derrida Encounter (1989). A succinct account is in C. Davis, Critical Excess (2010), at 26-55.

86 J. Derrida, Spurs, transl. by B. Harlow (1979), at 127 ['voile herméneutique'] (1978). I have modified the translation.

87 Id. ['perforer'].

88 J. Derrida, Monolingualism of the Other; or, the Prosthesis of Origin, transl. by P. Mensah (1998), at 39 ['structure coloniale'] (1996).

89 Derrida, above n. 86, at 127 ['le soustrait à toute question herméneutique assurée de son horizon']. I have modified the translation.

90 Id. ['éconduire tous les Schleiermacher, tous les faiseurs de voile']. I have modified the translation. Derrida's pun will not be lost on readers who have German.

91 J. Derrida, Edmund Husserl's Origin of Geometry: An Introduction, transl. by J.P. Leavey (1989), at 104 ['l'équivocité est en fait toujours irréductible'/'les mots et le langage en général ne sont et ne peuvent jamais être des objets absolus'] [1962]. I have modified the translation.

92 J. Derrida, Limited Inc., transl. by S. Weber (1988), at 63 ['Mille possibilités resteront toujours ouvertes'] [1990].

93 H.-G. Gadamer, 'Text and Interpretation', transl. by D.J. Schmidt and R. Palmer, in D.P. Michelfelder and R.E. Palmer (eds.), Dialogue and Deconstruction: The Gadamer-Derrida Encounter (1989), at 41 ['Das Befremdende, das einen Text unverständlich macht, soll durch den Interpreten aufgehoben werden'] (1983).

94 Gadamer, above n. 29, at 296 ['wirkliche Sinn']

95 See J. Derrida, 'Rams: Uninterrupted Dialogue - Between Two Infinities, the Poem', transl. by T. Dutoit and P. Romanski, in T. Dutoit and O. Pasanen (eds.), Sovereignties in Question (2005), at 149 ['un reste ou un excédent irréductible'] [2003].

${ }_{96}$ J. Derrida, Shibboleth: For Paul Celan, transl. by J. Wilner and T. Dutoit, in T. Dutoit and O. Pasanen (eds.), Sovereignties in Question (2005), at 26 ['Eradication du principe herméneutique' / 'totalisation interprétative'] (1986).
} 
One of Derrida's influential readers aptly observes that 'deconstruction is also the deconstruction of the concept of method' ${ }^{97}$ An early dispute involving Derrida and Claude Lévi-Strauss illustrates this claim. In 1962, when he released The Savage Mind (La Pensée sauvage), Lévi-Strauss, having been elected at the Collège de France three years earlier, had already established himself as a prominent anthropologist. In his book, he distinguishes between two modes of thought, which he associates with the bricoleur and the 'engineer', or 'scientist', respectively. ${ }^{98}$ Contrary to the bricoleur, who 'always [...] make[s] do with "whatever is at hand", 99 who "may not ever complete his purpose but [...] always puts something of himself into it', ${ }^{100}$ the engineer 'works by means of concepts', ${ }^{101}$ which 'aim to be wholly transparent with respect to reality' ${ }^{102}$ On the basis of 'the structures which [science] is constantly elaborating and which are its hypotheses and theories', ${ }^{103}$ against the background of 'a previously determined set consisting of theoretical and practical knowledge, of technical means, which restrict the possible solutions' ${ }^{104}$ the engineer addresses 'the universe' or 'nature' - as opposed to the bricoleur, who is concerned with 'culture'. ${ }^{105}$ In his reaction to Lévi-Strauss's distinction, Derrida forcefully holds that Lévi-Strauss's scientist is 'a myth'. ${ }^{106} \mathrm{He}$ writes as follows: 'The notion of the engineer who supposedly breaks with all forms of bricolage is [...] a theological idea'. ${ }^{107}$ According to Derrida, it is imperative 'that we cease to believe in such an engineer [as Lévi-Strauss's]', that we accept that 'the engineer and the scientist are also species of bricoleurs' and therefore 'that we admit that every finite discourse is bound by a certain bricolage' ${ }^{108}$ Derrida is emphatic: 'It must be said that every discourse is bricoleur. ${ }^{109}$

Derrida's resistance to what he himself stigmatizes as 'scientificist objectivism' or 'naive objectivism' cannot be taken to exclude the existence of some protocols for the reading of texts, ${ }^{110}$ what he calls 'a certain marching order'. ${ }^{111}$ (And Derrida agrees, of course, that there could be, if not a method, at least 'regularities in the ways of putting certain questions in a deconstructive style'. $)^{112}$ Indeed, 'it would be a great mistake to conclude that because deconstruction is critical of the [...] concept of method, it would [...] indulge in uncontrollable free play'. ${ }^{113}$ To be sure, '[a]lthough a deconstruction of method, deconstruction is not nonmethod, an invitation to wild and private lucubrations'. ${ }^{114}$

7 R. Gasché, The Tain of the Mirror (1986), at 123.

98 C. Lévi-Strauss, The Savage Mind, transl. by J. Weightman and D. Weightman (1966), at 16-22 ['bricoleur' / 'ingénieur' / 'savant' or 'homme de science'] (1962). The French word bricoleur is retained in the English translation: Id., at 17, not. For his part, Lévi-Strauss uses 'scientist' (savant or homme de science) alternatively with 'engineer': Id., at 19, 20 and 22.

99 Id., at 17 ['toujours s'arranger avec les "moyens du bord"'].

100 Id., at 21 ['Sans jamais remplir son projet, le bricoleur y met toujours quelque chose de soi'].

101 Id., at 20 ['opère au moyen de concepts'].

102 Id. ['se veut intégralement transparent à la réalité'].

${ }^{103}$ Id., at 22 ['(les) structures qu(e) (la science) fabrique sans trêve et qui sont ses hypothèses et ses théories'].

104 Id., at 19 ['un ensemble prédéterminé de connaissances théoriques et pratiques, de moyens techniques, qui restreignent les solutions possibles'].

105 Id. ['l'univers' / 'la nature' / 'la culture'].

106 J. Derrida, Writing and Difference, transl. by A. Bass (1978), at 285 ['un mythe'] [1967].

107 Id. ['L'idée de l'ingénieur qui aurait rompu avec tout bricolage est (...) une idée théologique'] (emphasis in English translation).

108 Id. ['qu'on cesse de croire à un tel ingénieur' / 'l'ingénieur ou le savant sont aussi des espèces de bricoleurs' / 'qu'on admet que tout discours fini est astreint à un certain bricolage'] (emphasis in English translation).

109 Id. ['on doit dire que tout discours est bricoleur'] (emphasis in English translation).

110 J. Derrida, Of Grammatology, rev'd transl. by G.C. Spivak (1997), at 61 ['objectivisme scientiste' / 'objectivisme naïf'] [1967].

111 J. Derrida, Dissemination, transl. by B. Johnson (1981), at 271 ['une certaine marche à suivre'] (1972).

112 J. Derrida, 'Qu'est-ce que la déconstruction?', Le Monde, 12 October 2004, 'Cahier', at iii ['des régularités dans les manières de poser un certain type de questions de style déconstructif’] (1992). This interview with Roger-Pol Droit first appeared posthumously, a few days after Derrida's death.

${ }_{113}$ Gasché, above n. 97, at 123

114 Id. 
The divergences between Gadamerian philosophical hermeneutics and Derridean deconstruction are profound. ${ }^{115}$ Thus, Gadamer would disagree with Derrida as he writes that ' $[\mathrm{b}]$ etween my world [...] and any other world there is first the space and the time of an infinite difference'. ${ }^{116}$ It is no doubt on account of this significant contrast between these "two interpretations of interpretation,"117 - which, for Derrida, are nothing short of 'absolutely irreconcilable" 118 - that Gadamer and Derrida's congruity of views on the inherent limits of understanding acquires so much significance.

\section{5}

My critical comparison of Habermas's discourse theory with Gadamer's philosophical hermeneutics and Derrida's deconstruction shows that, contrary to what some European lawyers have been suggesting, any mobilization of the Habermasian concept of 'discourse' cannot be regarded as pertinent in the current context of Europeanization of private laws. Indeed, when Habermas's proceduralist theory expresses the wish to 'poin [t] beyond the concrete ethos of a particular community or the worldview articulated in a particular tradition', ${ }^{119}$ it reveals how ill-adapted it is to a situation featuring 23 official languages, such as prevails within the European Union. Habermas simply lacks the sensitivity that would allow him to address the transcultural issue convincingly. Indeed, one of his critics insightfully observes how 'Habermas [...] does not have an ear for the plurality of voices in which reason can speak'. ${ }^{120}$ In the final analysis, the existence of a common discourse, as advocated by Habermas, or of a common European legal discourse, as argued by some European legal scholars, must be regarded as an exercise in wishful thinking. One can well accept, of course, the commendable motivations informing the idea. But the fact remains that one is faced with a project that cannot be achieved: the self and the other are destined to engage in negotiation, not to reach consensus.

It is important to emphasize that the impossibility of a common legal discourse should not be apprehended in strictly negative terms. On the contrary, we should value differences in understanding as they illustrate the benefits attendant upon intercultural communication. Because it allows for a diversity of views and fosters ongoing reflection through an incessant invitation to re-assess one's position, the absence of common discourse permits one to refine one's views. Look at it this way: What advantage would there be to derive from having coffee with someone whose discourse is common to mine? What would there be for me, or indeed for my interlocutor, to gather from this commonality? Where would be our challenge? In my view, European lawyers can learn something from Derrida's forceful assertion according to which '[what] we know in common [is] that we have nothing in common'. ${ }^{121}$ I would like to add that this is not at all bad news: Let the conversation continue!

\footnotetext{
115 See, for detailed exploration, G.W. Bertram, Hermeneutik und Dekonstruktion (2002); E. Angehrn, Interpretation und Dekonstruktion (2003).

116 J. Derrida, The Beast and the Sovereign, transl. by G. Bennington, Vol. II (2011), at 9 ['Entre mon monde (...) et tout autre monde, il y a d'abord l'espace et le temps d'une différence infinie'] (2002).

117 Derrida, above n. 106, at 292 ['deux interprétations de l'interprétation'].

118 Id., at 293 ['absolument irréconciliables'].

119 J. Habermas, 'Reply to Symposium Participants', transl. by W. Rehg, in M. Rosenfeld and A. Arato (eds.), Habermas on Law and Democracy: Critical Exchanges (1998), at 386.

120 N. Kompridis, Critique and Disclosure (2006), at 86.

${ }^{121}$ J. Derrida, 'I Have a Taste for the Secret', in J. Derrida and M. Ferraris, A Taste for the Secret, transl. by G. Denis, ed. by G. Denis and D. Webb (2001), at 58 ['sappiamo, in commune, di non avere nulla in commune'] [1997].
} 